\title{
Family Resources Management in Cibanteng Village, Ciampea, Bogor District
}

\author{
Risda Rizkillah ${ }^{*}$, Megawati Simanjuntak ${ }^{2}$ \\ ${ }^{1,2}$ Department of Family and Consumer Sciences, Faculty of Human Ecology, \\ IPB University, 16680, Indonesia \\ *Corresponding author: risdarizkillah@gmail.com
}

\begin{abstract}
Family resources are something that must be adequately managed that can be used optimally to achieve family goals. This study aims to analyze the process of family resource management include planning, task control, communication structure, decision making, and time allocation. This study applies a cross-sectional design. The location of data collection was conducted in the Cibanteng Village area, Ciampea District, Bogor Regency, West Java. The population in this study were families living in Cibanteng Village, Ciampea District. The sampling unit in this study is the family with the respondent is a wife. The sampling was taken purposively and obtained samples of 40 families. The results of the study showed that in the planning implementation, the majority of families never wrote their life plans in the family. The majority of mothers control domestic problems such as housework, children's education, and childcare. The structure of communication and decision making in the family carried out by the majority family only involves husband and wife. The higher the productive time allocated by the wife, the smaller the allocation of leisure time and household time. Also, the higher the social time allocation devoted by the wife, the smaller the allocation of household time and personal time allocation.
\end{abstract}

Keywords: decision making, family resources, management, planning, time allocation

\begin{abstract}
Abstrak
Sumber daya keluarga adalah sesuatu yang harus dikelola dengan baik sehingga dapat digunakan secara optimal untuk mencapai tujuan keluarga. Penelitian ini bertujuan untuk menganalisis proses manajemen sumber daya keluarga mencakup perencanaan, pengontrolan tugas, struktur komunikasi, pengambilan keputusan dan alokasi waktu. Studi ini menerapkan desain cross-sectional. Lokasi pengambilan data dilakukan di wilayah Desa Cibanteng Kecamatan Ciampea Kabupaten Bogor, Jawa Barat. Populasi pada penelitian ini adalah keluarga yang tinggal di Desa Cibanteng Kecamatan Ciampea. Unit sampling dalam penelitian ini adalah keluarga dengan responden istri. Pengambilan contoh dilakukan secara purposive dan didapatkan contoh sebanyak 40 keluarga dengan responden istri dalam suatu keluarga. Hasil penelitian menunjukkan bahwa pada pelaksanaan perencanaan mayoritas keluarga tidak pernah menuliskan perencanaan hidup di dalam keluarga. Mayoritas Ibu mengontrol masalah domestik
\end{abstract}


seperti pekerjaan rumah tangga, pendidikan, dan pengasuhan anak. Pada struktur komunikasi dan pengambilan keputusan dalam keluarga yang dilakukan oleh keluarga mayoritas hanya melibatkan suami istri saja. semakin tinggi alokasi waktu produktif yang dicurahkan oleh istri maka alokasi waktu santai dan alokasi waktu rumah tangga semakin kecil. Selain itu, semakin tinggi alokasi waktu sosial yang dicurahkan oleh istri maka alokasi waktu rumah tangga dan alokasi waktu pribadi semakin kecil.

Kata kunci: alokasi waktu, manajemen, pengambilan keputusan, perencanan, sumber daya keluarga

\section{Introduction}

Family is the smallest unit in society for individuals to grow and develop. The pattern of parenting applied in the family is one of the main aspects that significantly affects the quality of one individual to provide positive care and the environment in the family, in addition to the need for knowledge regarding parenting, the quality of family resources management is also much needed. Resources are something that is available and can be used to attain desired goals or everything single thing that is real or that believe has values. Resources are classified as tangible and intangible resources. Tangible resources are resources that can be touched, real, easy to measure, easily researched, for instance, land, money, jewelry, and houses. Whereas intangible resources are resources that are not visible, cannot be touched, e.g., are self-confidence, intelligence, integrity, ambition, and time.

All resources in the family must be adequately managed thus they can be used optimally to accomplish family objectives. Family resource management is an understanding of individual and family decision making regarding the development and allocation of resources such as time, money, material assets, energy, friends, neighbors, and territory in order to achieve goals (Simanjuntak, 2019). Management of family resources is a crucial role in realizing family well-being (Herawati et al., 2011). Besides, Fuaida (2007) also stated that the achievement of empowerment goals is also related to the ability of families to execute family resource management. The socioeconomic conditions of the family can be influential in the way management of resources.

This becomes a dynamic if the material resources are limited, but the lust is not limited, the time resources cannot be extended, diverse activities, limited human resources, limited expertise, diverse ego / personal desires, and lack of solidarity. If these things happen, the family needs an appropriate resource management system such as planning, organizing, implementing, and monitoring correctly, so in order to achieve family, goals will not be disrupted. Management allows individuals and families to survive and adapt from the various pressures and conditions, and also management becomes the way to confront the future. Management influences and is influenced by the internal and external environment in an ecosystem. Managerial actions are goal oriented and are related to owned or available resources (Deacon \& Firebaugh, 1988). Therefore, based on the background, this study aims to analyze the process of family resource management, including planning, controlling tasks, communication structures, decision making, and time allocation. 


\section{Method}

The study applies a cross-sectional design, namely research at the same time with different objects. The location of data collection is carried out in the Cibanteng Village area, Ciampea Sub-District, Bogor District, West Java, Indonesia. The population of this study was families with the wife as the respondents. Sampling was done purposively and obtained samples of 40 families. The observation of family resource management is completed by conducting direct interviews with 40 respondents who have the status as the wife in a family. The interviews conducted to refer to the questions listed on the family resource management questionnaire.

Planning is with whom the wife prepares her family plan consisting of four questions, for instance, are their family planning involves the father with the answers option are yes, no, and sometimes. Task control is who controls the tasks in the household, consisting of three questions, for example, do the father controls the family, and the choice provided is yes, no, and sometimes. The communication structure is involved in family communication, which consists of eight questions, for example, who are involved in discussing children's education issues? Moreover, the answer's options are father and mother; father, mother, and child; mother and brother; father and brother; mother and another, father and others. Decision making is a family pattern in deciding with 12 questions such as regarding children's education with the choice are a mother only, dominant mother, mother, and father, dominant father and father only. Time allocation is an open essay related to the mother's activities for 24 hours. Besides that, the author also carried out direct observation of the physical aspects of family resources to support the answers from the respondents.

Processing data is divided into two processes, namely descriptive statistics and inferential statistics. Data processing is done in the form of tabulations and correlations. The results of the tabulations and correlations were then analyzed to see an overview of resource management carried out by families in the Cibanteng Village area.

\section{Findings}

\section{Family Characteristics}

Husband's and wife's Age. The husband's age is in the age range of 22 to 75 years, and the average age of the husband is 41.43 years old. Half of the total husbands who are the samples are in the age range of 22 to 39 years old. Meanwhile, only five percent of husbands are in the age range of 58-76 years old (Table 1). The average age of the husband is 41.43 years old.Meanwhile, the average age of the wife is 35.63 years old and ranging between 20-65 years old. More than half the number of respondents aged between 20-35 years old is the productive age range. Conversely, there is only 7.5 percent of samples which are in the non-productive age, i.e., between the ages of 51-65 years. This means that most of the husband and wife are in the productive age category.

A number of household member. Following the study of family resource management, a family profile is needed, namely the number of household members. Household members are all individuals who occupy the same house and live together in one management. Family members are different from household members because family members are a group of people who have ties based on marriage, blood, and adoption but are not necessarily living together in one management. As much as 45 percents of household members consist of four to five people in number, showing that 
almost half are nuclear families consisting of husbands, wives and 2 to 3 children. A total of 45 samples have two to three children, and the rest have $0-1$ children.

Husband's and wife's job. Majority of the householder's job in Cibanteng village are laborers (30\%) like the construction laborers and freelancers. Meanwhile, the wife's job mostly as the housewife or not working 67.5 percents, and the rest are work as the trader (10\%), laundry laborers (5\%), and employees (17.5\%).

The income per capita. Most samples (75\%) in Cibanteng Village earn between IDR 0 - IDR 500.000 / capita. Concurrently, 17.5 percents have income between IDR 500.001-IDR 1.000.000 / capita and the rest (7.5\%) earns between IDR 1.000.001-IDR $1,500,000$ / capita.

Family expenses. About four-fifths (85\%) of the samples spending food costs amounted to IDR 0- IDR 1.000.000. Meanwhile, as many as 12.5 percents have food expenditure between IDR 1.000.001-IDR 2.000.000. A total of 70 samples spend nonfood costs of IDR 0-IDR 1.000.000. Also, there are 17.5 percents samples have food expenditure between IDR 1.000.001-IDR 2.000.000. While the rest (12.5\%) has expenditures between IDR 2.000.001- IDR 3.000.000.

Table 1 Family characteristics statistic

\begin{tabular}{|c|c|c|}
\hline Variables & $\mathrm{n}$ & $\%$ \\
\hline \multicolumn{3}{|l|}{ Husband's Age (years) } \\
\hline $22-39$ & 20 & 50 \\
\hline $40-57$ & 18 & 45 \\
\hline $58-75$ & 2 & 5 \\
\hline \multicolumn{3}{|l|}{ Wife's Age (years) } \\
\hline $20-35$ & 22 & 55 \\
\hline $36-50$ & 15 & 37.5 \\
\hline $51-65$ & 3 & 7.5 \\
\hline \multicolumn{3}{|c|}{ Number of Household Member (person) } \\
\hline $2-3$ & 11 & 27.5 \\
\hline $4-5$ & 18 & 45 \\
\hline $6-8$ & 11 & 27.5 \\
\hline \multicolumn{3}{|c|}{ Number of Children (person) } \\
\hline $0-1$ & 13 & 32.5 \\
\hline $2-3$ & 18 & 45 \\
\hline $4-6$ & 9 & 22.5 \\
\hline \multicolumn{3}{|l|}{ Income per Capita (IDR) } \\
\hline $0-500.000$ & 30 & 75 \\
\hline $500.001-1.000 .000$ & 7 & 17.5 \\
\hline $1000.001-1.500 .000$ & 3 & 7.5 \\
\hline \multicolumn{3}{|l|}{ Husband's Job } \\
\hline Unemployed & 1 & 2.5 \\
\hline Trader & 6 & 15 \\
\hline PNS/ ABRI & 1 & 2.5 \\
\hline Employee & 4 & 10 \\
\hline Laborer & 12 & 30 \\
\hline Farmer & 3 & 7.5 \\
\hline Entrepreneur & 7 & 17.5 \\
\hline Driver & 3 & 7.5 \\
\hline Apparatus (RT, headman) & 2 & 5 \\
\hline Died & 1 & 2.5 \\
\hline \multicolumn{3}{|l|}{ Wife's Job } \\
\hline Housewife/ unemployed & 27 & 67.5 \\
\hline Trader & 4 & 10 \\
\hline PNS/ ABRI & 0 & 0 \\
\hline
\end{tabular}


Rizkillah \& Simanjuntak / Journal of Family Sciences , 2018, Vol. 03, No. 02

\begin{tabular}{lcc}
\hline \multicolumn{1}{c}{ Variables } & $\mathrm{n}$ & $\%$ \\
\hline Employee & 7 & 17.5 \\
Laborer & 2 & 5 \\
\hline Food Expenditure (IDR) & & \\
$0-1000.000$ & 34 & 85 \\
$1000.001-2000.000$ & 5 & 12.5 \\
$2000.001-3000.000$ & 1 & 2.5 \\
\hline Non-Food Expenditure (IDR) & & \\
$0-1000.000$ & 28 & 70 \\
1000.001-2000.000 & 7 & 17.5 \\
$2000.001-3000.000$ & 5 & 12.5 \\
\hline
\end{tabular}

The number of children. Children have developmental stages that require distinct management. The children have more needs, both physically and psychologically. Ensure that the stages of child development need management. More than half (55\%) of the respondents do not have children aged under five years old (toddler), and 37.5 percents have one child under five years old. In addition, there are 72.5 percents of families that do not have preschoolers. Likewise of elementary school children, more than half of the families $(52.5 \%)$ do not have elementary school children. However, almost half $(45 \%)$ have elementary school children (Table 2 ).

Table 2 Sample distribution based on the number of children

\begin{tabular}{lcccccc}
\hline \multirow{2}{*}{$\mathrm{n}$} & \multicolumn{2}{c}{ Toddler } & \multicolumn{2}{c}{ Preschooler } & \multicolumn{2}{c}{$\begin{array}{c}\text { Elementary School } \\
\text { Children }\end{array}$} \\
\cline { 2 - 7 } & $\mathrm{n}$ & $\%$ & $\mathrm{n}$ & $\%$ & $\mathrm{n}$ & $\%$ \\
\hline 0 & 22 & 55 & 29 & 72.5 & 21 & 52.5 \\
1 & 15 & 37.5 & 11 & 27.5 & 18 & 45 \\
2 & 3 & 7.5 & 0 & 0 & 1 & 2.5 \\
Total & 40 & 100 & 40 & 100 & 40 & 100 \\
\hline
\end{tabular}

\section{Family Asset Ownership}

House. One of the most critical assets in family life is a house. House is one of the basic human needs functioned as a place to live and protects a person from the sway of the physical environment which directly related, such as rain, heat, sun, and wind. There are 60 percents of the samples have private homes with the ownership status. Meantime, only about 12.5 percents of families living in rented houses and the remaining $(27.5 \%)$ live with their parents (Table 3).

House Size. More than half of the samples (55\%) have houses with sizes between 10 $\mathrm{m}^{2}-80 \mathrm{~m}^{2}$. Only around 7.5 percent of respondents owning houses with the sizes between $151 \mathrm{~m}^{2}-220 \mathrm{~m}^{2}$, and the rest $(37.5 \%)$ having a house size between $81 \mathrm{~m}^{2}-150$ $\mathrm{m}^{2}$. Referring to the Criteria for Simple Houses / Rumah Sehat Sederhana (RSS) in Indonesia, the average house of the respondents has met the standard of RSS, which is between $21 \mathrm{~m}^{2}-36 \mathrm{~m}^{2}$.

Type and variety of roof. Based on the type of residence that is occupied, almost all the samples have lived in permanent homes (95\%). Only 5 percent of respondents live in houses with a semi-permanent type, and there are no family lives in a non-permanent home. Based on the Criteria for Simple Houses / Rumah Sehat Sederhana (RSS) in Indonesia, the criteria for a proper home are walled with brick and cemented can be called as a permanent home. Measuring from the type of roof used, almost all the 
samples having a house with a brick roof (97.5\%). Only around 2.5 percent of samples have a house with a roof in the form of leaves.

Defecation place. One of the criteria for a healthy home according to the Residential Environment World Health Organization (WHO) (1974) is to have latrines and bathrooms. Therefore, sanitation facilities are quite crucial in a house, including a place for defecation. In Cibanteng Village, almost all samples (92.5\%) have their toilets in their homes, which were used as sanitation facilities. While the other five percents still use public toilet facilities. All these toilets belong to the type of pit privy (latrines which are built near the tramp). The remaining 2.5 percents choose times or rivers to defecate, which are classified as an overhung latrine.

Vehicles, electronic devices, furniture, and livestock. The families interviewed were from middle to lower class families. This can be seen from the assets of vehicle ownership in each of these families. Only ten percents of families own four-wheeled vehicles, while more than a third (37.5\%) families have motorcycles that are used for daily transportation. This is due to the cost of buying the vehicle tends to be pricey, and the tax costs are also high. For short distance transportation, families in this area prefer to have a bicycle. It can be seen from the ownership of bicycle assets that reached more than half of the samples (52.5\%). For long-distance transportation, they usually use public transportation that can support their daily activities. For the ownership of electronic equipment, the majority of families prefer to use a fan (60\%), compared to using the air conditioner (AC) $(2.5 \%)$. Reason for this is that the costs for daily needs are quite tough to be fulfilled, while the cost of buying and installing air conditioners is expensive - moreover, the cost of electricity each month which tends to be high. To support family entertainment, more than half of the families $(55 \%)$ have radio/tape, and DVD / VCD (62.5\%). Meanwhile, for livestock ownership of 70 percents, they claim to have no livestock. The rest $(30 \%)$ claimed to have chicken and goat as their livestock also as an effort to add on the family income.

Table 3 Ownership of family assets statistics

\begin{tabular}{lcr}
\hline Assets Ownership & $\mathrm{n}$ & $\%$ \\
\hline House Ownership & 24 & 60 \\
Private Property & 5 & 12.5 \\
Rented & 11 & 27.5 \\
Live with the parents & & \\
\hline House's Size (m) & & 55 \\
$10-80$ & 22 & 37.5 \\
$81-150$ & 15 & 7.5 \\
$151-220$ & 3 & \\
\hline Roof Variety & 39 & 97.5 \\
Brick & 1 & 2.5 \\
Leaves & & \\
\hline Defecation place & 1 & 2.5 \\
River & 37 & 92.5 \\
Private Toilet & 2 & 5 \\
Public Toilet & & \\
Livestock & 12 & 30 \\
Yes & 28 & 70 \\
No & & \\
\hline
\end{tabular}




\section{Family Resources Management}

Planning. Management processes that are applied in family, such as things related to life goals. The sample states that family life goals are to attain education for children $(40 \%)$ and to have happy and loving families $(22.5 \%)$. A small percentage $(5 \%)$ of respondents stated that they had had more than one family goals they wanted to achieve. Less than one-fifth of the sample (17.5\%) always plans their life goals first while the rest are only sometimes planning to realize the goals $(65 \%)$, and 17.5 percents claimed never planning to achieve theirs. Not everything that becomes the purpose of life is planned, only important things like education and residence. The written plan was only carried out by 67.5 percents of the samples, while the rest did not write it down. The reason why they did not plan to achieve the goals is that it is not their habits, also education factors and the ability of the family to write them down also caused the planning not to be done in writing. They do it only by memorizing.

Task control. Every family's activity or family's issue is controlled by each family, namely the mother, father, and children. The respondent reveals that family activities are carried out by taking notes $(12.5 \%)$, fixing $(65 \%)$, or not taking notes but direct support ( $22.5 \%$ ). As many as 75 percents samples recognize domestic problems such as domestic work, education and childcare problems (15\%), and financial issues $(10 \%)$ whereas 70 percents of fathers could overcome public problems. Based on the results, children were also involved in controlling domestic activities (10\%), education problems (12.5\%), and parents health (2.5\%). However, most children oppose not participating in controlling any problems $(75 \%)$.

Communication structure. In communicating family matters, families are crucially needed, especially in making decisions relating to domestic affairs. Based on the results of the study, family members involved in family decisions are only limited to the husband. Such decisions were made regarding the determination of the number of children (94.8\%), family planning participation, and home ownership (85\%). In matters of education, more than half of the families $(56.4 \%)$ prefer to communicate the problem of education only between husband and wife. There is only 2.5 percent of respondents communicate with the relatives regarding the problem felt by mothers who work. As many as 27.5 percents chose wives to be as vehicle ownership and credit debt. This happened to the family did not meet the daily needs, the housewife took the initiative to borrow some money from the traveling creditors or the neighbors.

Decision-making. Family decision-making in determining the number of matters is dominated by joint decision making between father and mother including the decision for education of children (75\%), education level of children $(75 \%)$, and number of children $(82.5 \%)$, participation in family planning (KB) $(45 \%)$, decisions mothers work outside the home $(45 \%)$, home ownership (70\%), vehicle ownership (55\%), type of vehicle $(37.5 \%)$, using credit $(52.5 \%)$, and eating outside $(40 \%)$. Whereas decision making, which is dominated by mother or father only includes decision making to determine the daily menu (52.5\%) and food expenditure (60\%) (Table 4). Based on the results of the study, families with educated householder did not finish elementary school, tend to choose by his own or by his wife's. Whereas for families with a householder who have graduated from elementary school, the family decision making is classified as useful because it involves husband and wife. In families whose householder have graduated from Junior High School, the cooperation between husband and wife falls into the medium category, meaning that even though the husband and wife work together, it is not too intense. Meanwhile, the family led by a householder 
which graduated from Senior High School, husband and wife cooperation is high. In families whose family heads graduated from University, husband and wife cooperation in decision making is also high, because it has involved both husband and wife. In families whose husbands have died, decision-making is taken solely by the wife.

Table 4 Family decision making statistics

\begin{tabular}{|c|c|c|c|c|c|c|c|c|}
\hline \multirow{2}{*}{ Decision Making } & \multicolumn{2}{|c|}{0} & \multicolumn{2}{|r|}{1} & \multicolumn{2}{|c|}{2} & \multicolumn{2}{|r|}{3} \\
\hline & $\mathrm{n}$ & $\%$ & $\mathrm{n}$ & $\%$ & $\mathrm{n}$ & $\%$ & $\mathrm{n}$ & $\%$ \\
\hline Children's type of education & 1 & 2.5 & 3 & 7.5 & 6 & 15 & 30 & 75 \\
\hline Children's level of education & 1 & 2.5 & 3 & 7.5 & 6 & 15 & 30 & 75 \\
\hline Number of children & 0 & 0.0 & 4 & 10.0 & 3 & 7.5 & 33 & 82.5 \\
\hline The participation of family planning (KB) & 6 & 15.0 & 13 & 32.5 & 3 & 7.5 & 18 & 45.0 \\
\hline Mother work outside the house & 1 & 2.5 & 14 & 35.0 & 7 & 17.5 & 18 & 45.0 \\
\hline House ownership & 0 & 0.0 & 7 & 17.5 & 5 & 12.5 & 28 & 70.0 \\
\hline Vehicle ownership & 8 & 20.0 & 4 & 10.0 & 6 & 15.0 & 22 & 55.0 \\
\hline Vehicle's type & 9 & 22.5 & 6 & 15.0 & 10 & 25.0 & 15 & 37.5 \\
\hline Credit uses & 9 & 22.5 & 4 & 10.0 & 6 & 15.0 & 21 & 52.5 \\
\hline Daily menu & 0 & 0.0 & 21 & 52.5 & 15 & 37.5 & 4 & 10.0 \\
\hline Food expenditure & 0 & 0.0 & 24 & 60.0 & 12 & 30.0 & 4 & 10.0 \\
\hline Eat outside & 8 & 20.0 & 8 & 20.0 & 8 & 20.0 & 16 & 40.0 \\
\hline $\begin{array}{l}\text { Note }: \quad 0=\text { not specified } \\
1=\text { only wife or only husband } \\
2=\text { wife/ husband dominant } \\
3=\text { wife or husband }\end{array}$ & & & & & & & & \\
\hline
\end{tabular}

Time Allocation. As many as 72.5 percents of wives have productive time allocations ranging from 0-3 hours per day. Fewer wives have a productive time of 4-6 hours and 7-9 hours per day or as much as 15 percent and 12.5 percent. The data illustrates that most of the wife's productive time is quite limited, which is only 0-3 hours per day. The allocation of time to relax is half the sample (50\%) around $0-5$ hours per day. One in eight samples (12.5\%) still allocate leisure time of around 11-15 hours per day. More than half $(52.5 \%)$ of the sample spend time on social activities around 02 hours per day. The allocation of wife's time for more domestic work is spent in the time range of 5-8 hours per day (47.5\%), and then with an allocation of 0-4 hours per day (40\%), and only 12.5 percents who allocates his or her time in the range of 9-12 hours per day for housework. Then for the allocation of wife's time related to personal activities, it is divided almost equally with the time categories of 0-5 hours per day (35\%), 6-8 hours per day (38\%), and 11-15 hours per day (28\%) (Table 5).

Table 5 Wife's time allocation statistics

\begin{tabular}{lcr}
\hline Time Allocation & $\mathrm{n}$ & \\
\hline Productive Time (hours) & & \\
$0-3$ & 29 & 72.5 \\
$4-6$ & 6 & 15 \\
$7-9$ & 5 & 12.5 \\
\hline Wife's Leisure Time (hours) & & 50 \\
$0-5$ & 20 & 37.5 \\
$6-10$ & 15 & 12.5 \\
$11-15$ & 5 & \\
\hline
\end{tabular}




\begin{tabular}{lcr}
\hline Time Allocation & $\mathrm{n}$ & \\
\hline $\begin{array}{l}\text { Wife's Socializing Time } \\
\text { (hours) }\end{array}$ & & \\
$0-2$ & 21 & 52.5 \\
$3-5$ & 18 & 45 \\
$6-8$ & 1 & 2.5 \\
\hline Wife's Social WorkTime & & \\
(hours) & 16 & 40 \\
$0-4$ & 19 & 47.5 \\
$5-8$ & 5 & 12.5 \\
$9-12$ & & \\
\hline Wife's Private Time (hours) & 14 & 35 \\
$0-5$ & 15 & 38 \\
$6-10$ & 11 & 28 \\
$11-15$ & & \\
\hline
\end{tabular}

\section{Correlation}

The correlation test results show that productive time allocation has a significant negative relationship with leisure time allocation and household time allocation, meaning that the higher the productive time allocation handled by the wife, the lesser leisure time allocation and the allocation of time for the household. Social time allocation also has a significant negative relationship with household time allocation and private time allocation. This means that the higher the social time allocation devoted by the wife, the smaller the allocation of household time and private time allocation (Table 6).

Table 6 Correlation test between allocation time and wife's job

\begin{tabular}{lc|c|c|c|c}
\hline Variables & 1 & 2 & 3 & 4 & 5 \\
\hline 1 & 1 & - & - & - & - \\
2 & $-0.365^{*}$ & 1 & - & - & - \\
3 & 0.013 & 0.225 & 1 & - & - \\
4 & $-0.338^{*}$ & -0.257 & $-0.334^{*}$ & 1 & 1 \\
5 & -0.262 & -0.522 & $-0.444^{* *}$ & -0.094 & \\
\hline Note: **) significant at $\mathrm{p}<0.05$ & & \\
$1 . \quad$ Productive time allocation & & \\
$2 . \quad$ Leisure time allocation & & \\
3. Social time allocation & &
\end{tabular}

\section{Discussion}

Based on the households' profile in Cibanteng Village, Ciampea Sub-District, Bogor Regency, most of the age of husband and wife are in the productive age range. Most families are also categorized as nuclear families consisting of husbands, wives, and only one to three children. About two out of three families have teenagers. Based on the social and economic characteristics of the family, almost one-third of the householder has a type of job as a laborer, and most wives do not have jobs in the public sector. One-third of husbands and wives only have an education until they finish elementary school.

The process of family resource management performed by the family usually commences with making plans carried out by the family. According to Olson and Beard 
(1985), planning is part of a managerial system that accepts goals, and other requests serve to collect information about alternative characteristics both qualitatively and quantitatively, which have potential. The main goal that the family wants to achieve is a good education for children and having a joyful family. However, in its implementation, two out of three families never wrote their life plans because it is not their habit, the factor of education and the family's ability to write down the lists are also the reason of the planning not being done in writing. They have done it only by memorizing. The finding of the study is supported by the results of Iskandar (2008) and Simanjuntak (2010) which states that the practice of financial resource management is classified as low in low-income families because of the income they have is not regular. Thus financial planning is quite minimal. Further, according to Faradillah, Lasmanawati, \& Rahmawati (2013), the reason why a person lacks understanding of financial planning in long-term and short-term goals is that it does not implement personal financial management.

The family controls its planning by taking notes, correcting, or not making notes but applying them directly. The majority of wives control domestic issues such as housework, education, and childcare. In line with the research of Saleha, Hartoyo, and Hastuti (2008) and Ariyanto (2004), which states that the time allocated to domestic activities is more owned by wives than husbands. The structure of communication in the family carried out by the majority of families is only involving husband and wife. For instance, in making decisions related to the determination of the number of children, family planning participation, child education problems, and home ownership. In line with Iskandar (2008) which states that most mothers communicate many things with their spouses that they can both try to realize the plans that have been made. The most significant percentage of the involvement in considering decisions is included when the family overcomes food problems. This is possible because of their close intimacy and adjacent housing, making it easy for families to ask for help, especially when experiencing food problems.

Family decision making in determining the number of issues is dominated by joint decision making between husband and wife including deciding children's education, a number of children, participation in family planning, the decision of the wife to work outside the home, home ownership, vehicle ownership, taking credit, and eating out. The householder who has graduated from Higher Education (HE) has a relatively high level of cooperation between couples compared to the householder whose education is lower than HE. This is in line with the results of the research of Hakim, Sunarti, and Herawati (2014) which states that the better the level of education of a person, the better financial management will be carried out, in this case including cooperation between husband and wife.

Based on the wife's time allocation, the majority of wives have productive time allocations ranging from 0-3 hours per day. The available data illustrates that most of the wife's productive time is limited to only 0-3 hours per day. Allocation of time to relax is half an example of 0-5 hours per day and for social activities 0-2 hours per day. The allocation of wife's time for housework is more spent in the time range of 5-8 hours per day, while the allocation of wife's time related to personal activities is divided almost equally with the categories of time spent as much as 0-5 hours per day, 6-8 hours per day and 11-15 hours per day. Based on the type of time allocated by the wife, the allocation of time for domestic work has the highest allocation. Rosmawati, Rianda, and Taridala (2016) stated that the amount of time spent by wives in household activities 
was higher than the time devoted by husbands. This is because the wife is responsible for household work that needs more time. The housework is carried out before and after making a living.

The higher the productive time allocation that is handled by the wife, the smaller the allocation of time and the allocation of time for the household. This can happen to wives who work in the public sector. They have a double burden, namely at work and at home. The standard working hours in the public sector are eight hours per day, making the allocation of leisure time and allocation of the wife's household time smaller. Furthermore, the higher the social time allocation that the wife devotes, the smaller the allocation of household time and private time allocation. This can happen to the wife who is active in social activities outside the home such as social gathering, recitation, social service, which consumes enough time so that the allocation of household time and the allocation of wife's personal time are subordinate.

\section{Conclusion and Recommendation}

\section{Conclusion}

The majority of husbands and wives are in the productive age range and are nuclear families consisting of husbands, wives, and only have one to three children. Almost one-third of the husband have jobs as laborers, and most wives do not have jobs in the public sector. One-third of husbands and wives only get an education until they finish elementary school.

The big goal that the family wants to achieve is the education of good children and having a happy family. However, in practice, the majority of families never write their life plans. Families control their planning by making notes, fixing, or others not making notes but directly implementing them. Domestic problem management as, housework, education, and childcare mostly done by the wives. Conversely, in the family communication structure and decision making husband and wife involved. The well-educated householder tends to have better cooperation than families with lower education.

The available data illustrates that most productive wives are quite limited to only 0-3 hours per day. Half the samples spend time relaxing around 0-5 hours per day and for social activities 0-2 hours per day. The allocation of wife's time for housework is more spent in the time range of 5-8 hours per day, while for the allocation of wife's time related to private activities is divided almost equally with the time category of $0-5$ hours per day, 6-8 hours per day, and 11-15 hours per day.

Based on the correlation test results, the higher the productive time allocation that the wife devotes, the less relaxed time allocation and the allocation of household time. Additionally, the higher the social time allocation that the wife devotes, the smaller the allocation of household time and private time allocation.

\section{Recommendation}

The management process should be applied to every family to achieve a better life goal. The stages of family resource management begin with communication, planning, and division of tasks. It is better to discuss family matters, both financial, parenting, and education for children, and home ownership involving all family members. In order to create the same goal and can reduce conflict in the family. In 
addition, there is a need for written and detailed planning in the family to determine life goals in order to reduce the risk of failure in the household.

\section{References}

Ariyanto. (2004). Alokasi Waktu dan Ekonomi Rumah Tangga Pekerja pada Sektor Industri Formal Berdasarkan Gender (thesis). Sekolah Pascasarjana. Institut Pertanian Bogor. Bogor.

Deacon, R.E., Firebaugh F.M. (1988). Family Resource Management; Principle and Application (2nd Ed.). United State of America: Allyn and Bacon Inc.

Fadillah. D.K., Lasmanawati, E., Rahmawati, Y. (2013). Penerapan hasil belajar manajemen sumber daya keluarga pada pengelolaan keuangan mahasiswa pendidikan tata boga. Media Pendidikan, Gizi dan Kuliner, 2(1), 16-23.

Fuaida, L. D. (2007). Manajemen Keuangan Keluarga Miskin: "Studi Kasus Mitra Program Masyarakat Mandiri, Dompet Dhuafa Republika.”(thesis). Sekolah Pascasarjana, Universitas Indonesia, Depok.

Hakim, F.A., Sunarti, E., Herawati, T. (2014). Manajemen keuangan dan kepuasan keuangan istri pada keluarga dengan suami istri bekerja. Jurnal Ilmu Keluarga dan Konsumen,7(3),174-182.

Herawati, T., Ginting, B. S., Asngari, P. S.,Susanto, D., Puspitawati, H. (2011). Manajemen sumber daya keluarga peserta program pemberdayaan masyarakat di kabupaten Bogor. Jurnal Penyuluhan,7(2),38-47.

Iskandar, A. B. (2008). Analisis praktik manajemen sumber daya keluarga dan dampaknya terhadap kesejahteraan keluarga di kabupaten dan Kota Bogor.Jurnal transdisiplin sosiologi, komunikasi, dan ekologi manusia, 2(1), 8198.

Olson, G.I., Beard D.M. (1985). Assessing Managerial Behaviour. Journal of Family and Economic Issues.

Rosmawati, Rianada, L., Taridala, A. A. (2016). alokasi waktu jender dalam rumah tangga nelayan budidaya rumput laut di Kabupaten Buton Utara Sulawesi Tenggara. Jurnal Bisnis Perikanan FPIK UHO,3(1), 19-30.

Saleha, Q., Hartoyo, Hastuti, D. (2008). Manajemen sumberdaya keluarga: suatu analisis gender dalam kehidupan keluarga nelayan di pesisir Bontang Kuala, Kalimantan Timur.Jurnal Ilmu Keluarga dan Konsumen, 1(2).

Simanjuntak, M. (2010). Faktor-faktor yang memengaruhi kesejahteraan keluarga dan prestasi belajar anak pada keluarga penerima program keluarga harapan $(P K H)$ (tesis). Sekolah Pascasarjana, Institut Pertanian Bogor, Bogor.

Simanjuntak, M. (2019).Manajemen Sumber Daya Untuk Individu Dan Keluarga. Edisi $\mathrm{Ke}$-1.Terjemahan : Resource Management For Individuals And FamiliesEdisi ke-4. Elizabeth B. Goldsmith2010. Departemen Ilmu Keluarga dan Konsumen, Fakultas Ekologi Manusia, Institut Pertanian Bogor. 